\title{
Expression of a homeo domain protein in noncontact-inhibited cultured cells and postmitotic neurons
}

\author{
W.F. Odenwald, C.F. Taylor, F.J. Palmer-Hill, V. Friedrich, Jr., M. Tani, ${ }^{1}$ and R.A. Lazzarini \\ Laboratory of Molecular Genetics, NINCDS, National Institutes of Health, Bethesda, Maryland 20892 USA
}

The murine Hox 1.3 gene is one of six homeo box genes clustered on chromosome 6. Our analysis of Hox 1.3 cDNA and genomic clones indicates that the gene is organized into two exons and encodes a 270-amino-acid homeo domain protein. The predicted protein is rich in serine, glycine, and proline residues, and its homeo domain is identical to the Hox 2.1 domain. During embryogenesis, the gene is maximally expressed at midgestation but is also expressed to a lesser extent in many adult tissues possessing different cell lineages. Hox 1.3 transcripts are also present in cultured fibroblasts. The Hox 1.3 protein accumulates in the nuclei of nonconfluent cultured fibroblasts but is greatly diminished in contact-inhibited, nongrowing cells. Thus, the expression of the Hox 1.3 gene correlates with growth in embryos and cultured cells. Paradoxically, it is also expressed in certain subsets of postmitotic, fully differentiated neurons, most notably the Purkinje neurons of the cerebellum, the pyramidal and dentate neurons of the hippocampus, and the motor neurons of the spinal cord. This complex pattern of expression suggests that $\operatorname{Hox} 1.3$ may provide a function required by many cell types in addition to any role it may have in morphogenesis.

[Key Words: Murine Hox 1.3; homeo box gene; protein immunolocalization]

Received March 4, 1987; revised version accepted April 21, 1987.

The development of body pattern during embryogenesis involves complex molecular systems that convey and utilize positional and temporal information. As a result of these cues, cells acquire different morphogenic properties (mitotic rates, cell-cell recognition, migration rates, etc.) that result in a differential pattern of morphogenesis within the developing embryo. One of the early events in Drosophila development is the formation of segments along the anterior-posterior axis of the embryo that gives rise to the body parts of the larvae. Mutations affecting this process define sets of genes called segmentation and homeotic genes, which control the number, polarity, and identity of larval segments $(\mathrm{Ou}-$ weneel 1976; Nüsslein-Volhard and Wieschaus 1980). Consistent with their proposed morphogenic role, these genes display both temporal and spatial restrictions in their expression during normal development. The recent isolation and molecular characterization of the segmentation and homeotic genes have revealed that their encoded proteins are likely to be components in the regulatory program controlling Drosophila development. Many of these proteins share a highly conserved 60-

${ }^{1}$ Howard Hughes Medical Institute Research Scholars Program. amino-acid domain known as the homeo domain (McGinnis et al. 1984a,c; Scott and Weiner 1984). Amino acid sequence comparisons to known DNAbinding regulatory proteins indicate that one of the homeo domain's functional roles may be DNA binding (Laughon and Scott 1984; Shepherd et al. 1984). Immunolocalization of the Drosophila homeo domain proteins caudal (cad) (Macdonald and Struhl 1986), fushi tarazu (ftz) (Carroll and Scott 1985), engrailed (en) (DiNardo et al. 1985), Antennapedia (Antp) (Carroll et al. 1986; Wirz et al. 1986), and Ultrabithorax (Ubx) (White and Wilcox 1984; Beachy et al. 1985) have shown that they are concentrated in the nuclei of cells within specific regions of the developing embryo. Furthermore, fusion peptides containing the en homeo domain or the murine Hox 1.5 homeo domain bind to DNA in a sequence-specific manner (Desplan et al. 1985; Fainsod et al. 1986).

Related genes in vertebrates and mammalian species have been identified by hybridization to the Drosophila homeo boxes at reduced stringencies. Many of these mammalian genes share characteristics with the Drosophila segmentation and homeotic genes, and the expectation is that they too play important roles in morphogenesis (for review, see Manley and Levine 1985). However, important characteristics of homeo box genes 
suggest that the proteins they encode may have additional or alternate functions. For example, homeo box sequences have been identified in a wide range of animals that possess seemingly different developmental strategies and show little or no evidence of segmentation (McGinnis et al. 1985; Holland and Hogan 1986). In addition, the phylogenetic distribution of the Antp-like homeo box sequences shows no apparent correlation with any development program (Holland and Hogan 1986). Second, a recurrent feature among many of the mammalian homeo box genes is their expression in adult tissues. Every mouse homeo box gene whose adult expression has been examined in detail has been found to be expressed in adult tissues as well as embryonic tissues [Hox 1.1 and Hox 1.2 (Colberg-Poley et al. 1985b); Hox 1.4 (Duboule et al. 1986; Rubin et al. 1986; Wolgemuth et al. 1986); Hox 1.5 (Ruddle et al. 1985); Hox 2.1 (Jackson et al. 1985; Ruddle et al. 1985); Hox 3 (Awgulewitsch et al. 1985)|. The investigations of the expression of these genes in adult tissues have been limited because the techniques employed, that is, in situ hybridization and Northern blot analysis, do not easily yield cellular morphologic information. Consequently, the type and location of the expressing cells have not been determined and the correlations between expression and possible function have not been made.

In this paper, we report the identification and characterization of a mouse gene, the Hox 1.3 gene, and the homeo domain protein that it encodes. With the aid of cDNA and genomic clones, we describe the gene and its organization. Northern blot analysis shows that in addition to its embryonic expression, Hox 1.3 message is present in many adult tissues that have diverse cell lineages. The $\operatorname{Hox} 1.3$ gene specifies a 270 -amino-acid protein that is rich in serine, glycine, and proline residues and concentrated in the nuclei of expressing cells. We have synthesized a set of oligopeptides that correspond to different portions of the predicted amino acid sequence outside the homeo domain and raised antibodies specific for them. This set of immune reagents has allowed us to study the expression of the protein in cultured cells and in sections of adult mouse tissue. The expression of the Hox 1.3 protein is exquisitely sensitive to the growth of cultured mouse fibroblasts. Cells with few cell-cell contacts in growing cultures accumulate the protein in their nuclei, whereas nondividing, contact-inhibited cells do not. Within $30 \mathrm{~min}$ of removal of the contact inhibition, cultured cells concentrate significant amounts of the Hox 1.3 protein in their nuclei. The regulation of the $\operatorname{Hox} 1.3$ protein exhibits an interesting paradox. It is expressed in embryonic tissues and in cultured cells in a way suggesting a direct correlation with growth or cell division. Nonetheless, the Hox 1.3 protein is also expressed in particular subsets of postmitotic, fully differentiated neurons of the adult animal. Most notable among these are the Purkinje neurons of the cerebellum, the pyramidal and dentate neurons of the hippocampus, and the motor neurons of the spinal cord. This complex pattern of expression suggests to us that the Hox 1.3 protein may perform a function common to many developmentally diverse cell types.

\section{Results}

\section{Characterization of murine Hox 1.3 cDNA and genomic sequences}

DNA encoding the Antp homeo box (McGinnis et al. 1984a) was employed as a probe to screen a $\lambda$ gt $11 \mathrm{cDNA}$ library prepared from 18-day postnatal BALB/c mouse brain poly(A) ${ }^{+}$RNA (Kamholz et al. 1986). The library contained 150,000 recombinant phage. Screening several library equivalents under reduced stringency yielded a single positive clone. DNA sequence analysis of a 1576bp cDNA (cגmb-1) isolated from this phage revealed an Antp-class homeo box (Regulski et al. 1985) positioned $532 \mathrm{bp}$ from its $5^{\prime}$ end. The DNA sequence of $\mathrm{c} \lambda \mathrm{mb}-1$ is shown in Figure 1. Probes prepared from sequences flanking the cDNA's homeo box were, in turn, used to isolate five overlapping $\lambda$ genomic clones from a BALB/c mouse genomic library. Restriction site mapping demonstrated that the overlapping clones spanned $30 \mathrm{~kb}$ of genomic sequences. Southern analysis of these clones, using the cDNA homeo box, indicated that there were four separate homeo box homologies within these sequences (data not shown). This homeo box cluster was identified as part of the Hox 1 locus, located on bands B $3 \rightarrow$ C of chromosome 6 (Colberg-Poley et al. 1985a,b; Búcan et al. 1986; Duboule et al. 1986) by the following criteria: congruency of the homeo box positions and restriction endonuclease sites, and sequence homology as revealed by hybridization at high stringency, with portions of the $\lambda$ m- 6 Hox 1 genomic clone /Colberg-Poley et al. 1985a) not containing homeo box sequences. Our genomic clones represented the first $30 \mathrm{~kb}$ of the Hox 1 locus and contained Hox 1.1-Hox 1.4 homeo boxes (Fig. 2). Under high-stringency hybridization conditions, cDNA probes that did not contain the homeo box hybridized to sequences flanking the Hox 1.3 homeo box, indicating that the cDNA was derived from the Hox 1.3 gene. We have determined the DNA sequence of $3.5 \mathrm{~kb}$ surrounding the Hox 1.3 homeo box and confirmed that the cDNA represents part of the Hox 1.3 transcriptional unit. Alignment of cDNA sequences with $\operatorname{Hox} 1.3$ genomic sequences identified a 960 -bp intron, located 21 bp upstream from the homeo box (Figs. 1 and 2). With the exception of the intron and poly(A) tail, cDNA and Hox 1.3 genomic sequences are identical.

As shown in Figure 1, the entire $3^{\prime}$ exon /containing the homeo box) is present in the cDNA, together with $501 \mathrm{bp}$ of the upstream exon. Based on the size of the major Hox 1.3 transcript $(\sim 1.85 \mathrm{~kb}$, see Fig. 3$)$, we believe that the cDNA lacks approximately 275-300 nucleotides of the mature mRNA. Assuming an average poly(A) tail of 175 nucleotides, we estimate that the cDNA is missing approximately 150 nucleotides at its $5^{\prime}$ end. Analysis of 400 bp of genomic sequence upstream from the $5^{\prime}$ end of the cDNA reveals a single in-frame initiator AUG codon, positioned $61 \mathrm{bp}$ from the cDNA's $5^{\prime}$ end (Fig. 1). Translation initiated at this codon would produce a 270-amino-acid, 29,273-dalton homeo-domain-containing protein. Sequences surrounding the adenine nucleotide, positioned $150 \mathrm{bp}$ from the end of 
Odenwald et al.

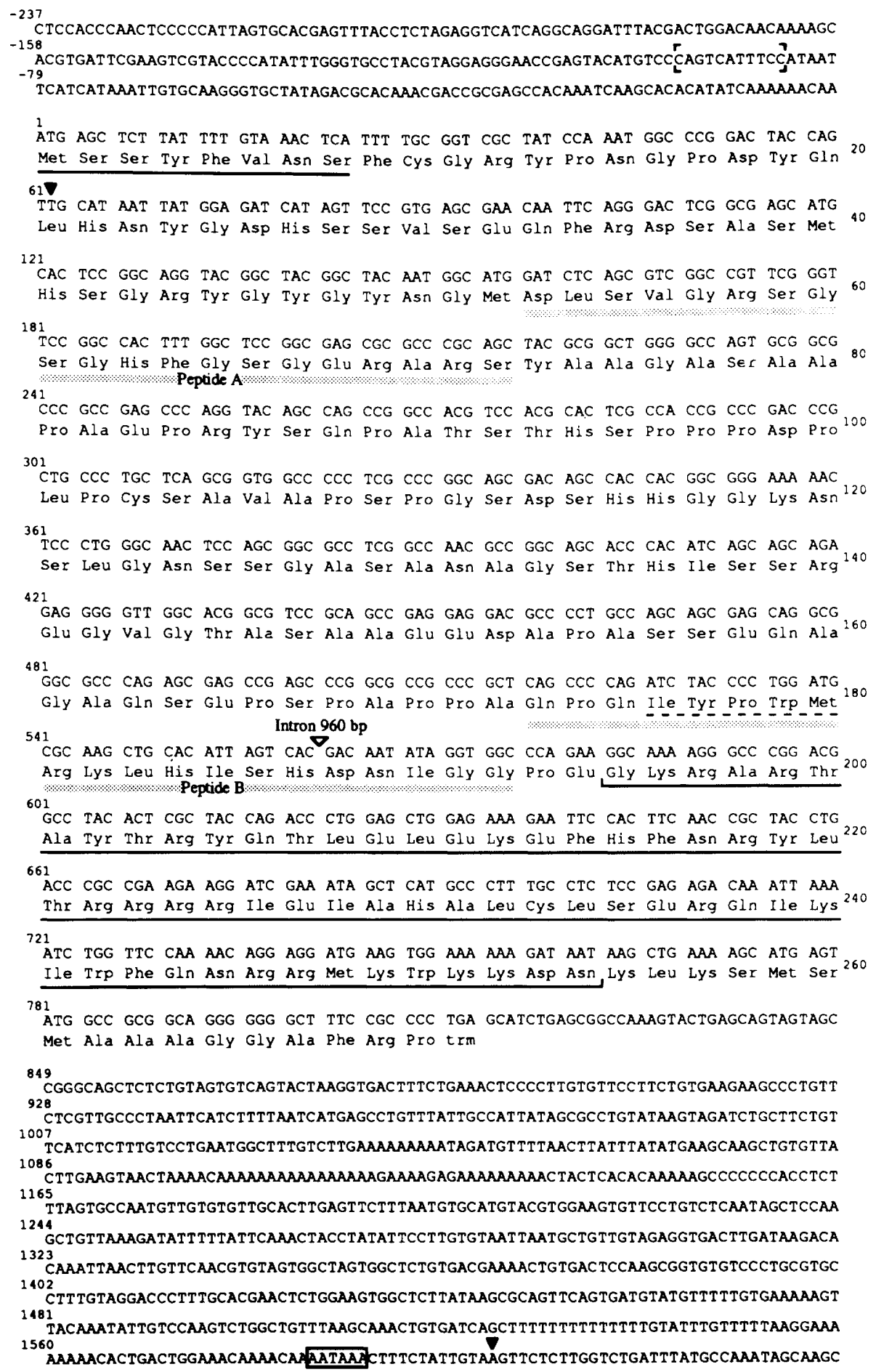

Figure 1. DNA and predicted protein sequences of murine $\operatorname{Hox} 1.3$. The nucleotide sequence represents a composite of sequences obtained from both strands of the cDNA and genomic Hox 1.3 DNA. Numbering begins at the predicted translation start codon. cDNA boundaries, excluding the $3^{\prime}$ poly(A) tail of 32 residues, are denoted by arrowheads. Nucleotide sequences -95 to -85 (indicated by brackets) are homologous to the consensus eukaryotic capping site (see text). The underlined amino-terminal amino acid residues show a high degree of homology to amino-terminal residues of the predicted human HHO.c13 homeo domain containing protein: Met-Ser-Ser-Tyr-Met-Val-Asn-Ser (Mavilio et al. 1986). Amino acid residues 53-72 and 173-192 (brackets) correspond to oligopeptides $\mathrm{A}$ and $\mathrm{B}$, respectively, which were employed to raise anti-Hox 1.3 antibodies (see text). The sequence from position (dashed underline) 525 to 540 is shared by several homeo box genes (Mavilio et al. 1986). The Hox 1.3 homeo box is underlined with a solid line. A consensus polyadenylation signal (boxed) is located 13 nucleotides upstream from the cDNA's poly(A) tail (not shown). 


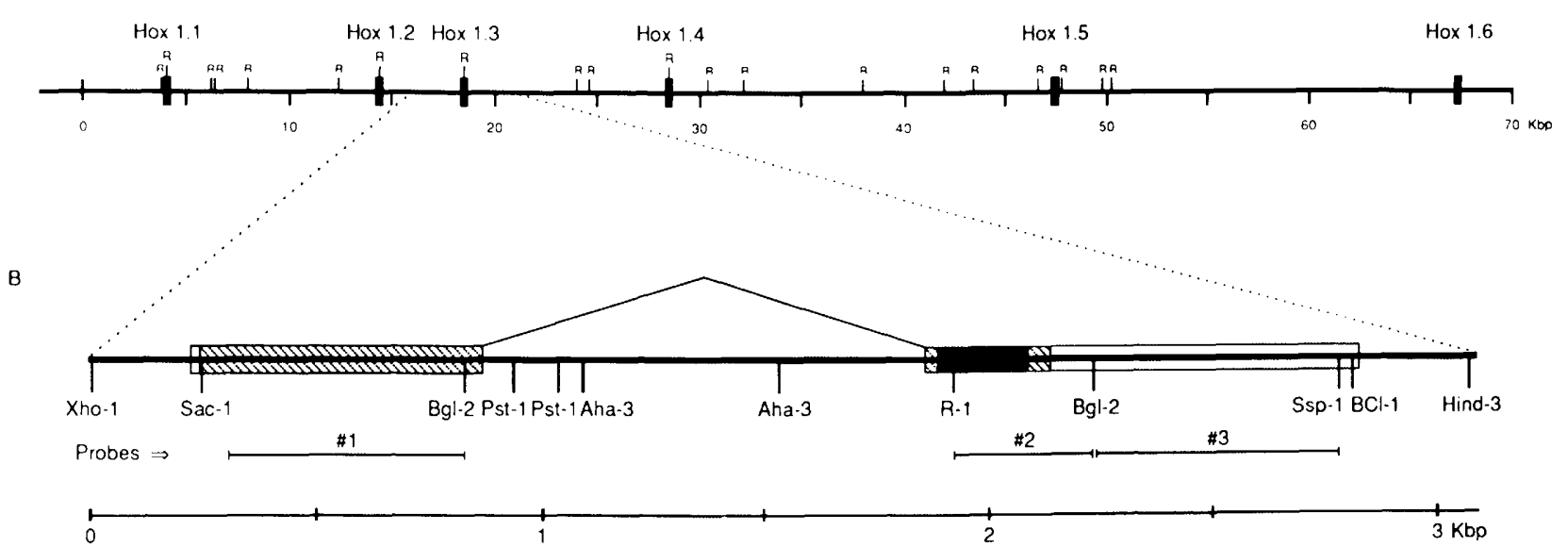

Figure 2. The murine Hox 1 cluster. (A) EcoRI restriction map of the Hox 1 cluster compiled from Colberg-Poley et al. (1985b) and Duboule et al. (1986), showing the current homeo box nomenclature (Martin et al. 1987). Hox 1.1, also known as (a.k.a.) m6 (ColbergPoley et al. 1985a,b); Hox 1.2, a.k.a. m5 (Colberg-Poley et al. 1985b); Hox 1.3, a.k.a. m2 and Hox 1-x (Colberg-Poley et al. 1985b; Duboule et al. 1986); Hox 1.4, a.k.a. HBT-1, MH-3, and Hox 1-3 (Duboule et al. 1986; Rubin et al. 1986; Wolgemuth et al. 1986); Hox 1.5, a.k.a. MO-10 and Hox 1-4 (McGinnis et al. 1984a; Duboule et al. 1986); Hox 1.6, a.k.a. Hox 1-y (Duboule et al. 1986). (B) Expanded restriction endonuclease map of the Hox 1.3 gene showing the predicted boundaries of the major 1.85 -kb transcript (boxes). The hatched regions correspond to the predicted protein-encoding sequences, which are separated by a 960 -bp intron. The solid rectangle delineates the homeo box. Probes 1, 2, and 3 represent subcloned cDNA sequences that were employed as hybridization probes for both genomic identification and Northern analysis of Hox 1.3 expression.

the cDNA (Fig. 1), are homologous with the consensus eukaryotic capping site PyxxxPyA $(\mathrm{Py})_{s}$ (Breathnach and Chambon 1981) and may represent the $5^{\prime}$ end of the major transcript. Although there is an AT-rich sequence 36 bp upstream from this consensus cap site, this sequence lacks a typical Goldberg-Hogness TATA box. No consensus acceptor splice sites were found in these upstream sequences (Mount and Steitz 1984). Although at this time we cannot rule out the possibility that the major Hox 1.3 transcript contains an additional 5' exon, the data suggest that the cDNA is missing the $5^{\prime}$ end of the major Hox 1.3 transcript and that the protein-encoding sequences are derived from two exons.

The hexanucleotide repeat ACAAAA, present in the $5^{\prime}$ and $3^{\prime}$ untranslated regions of the Krüppel (Rosenberg et al. 1986) and fushi tarazu (Laughon and Scott 1984) Drosophila segmentation genes, is present a total of 13 times in Hox 1.3 sequences. The repeat occurs twice in the 180 -bp region $5^{\prime}$ to the predicted protein-coding region, twice in the intron, and nine times in the 792-bp 3' untranslated region. The $3^{\prime}$ untranslated portion of the Hox 1.3 transcript also contains AU-rich regions that have been shown to confer mRNA instability (Shaw and Kayman 1986).

\section{Murine Hox 1.3 protein}

The predicted primary structure of the Hox 1.3 protein is shown in Figure 1. The 270 -amino-acid long protein is rich in serine $(14 \%)$, glycine $(10 \%)$, and proline $(7.8 \%)$ amino acid residues. Like other homeo box genes (reviewed in Laughon et al. 1985), the homeo domain is positioned near the carboxyl terminus. Comparison of the Hox 1.3 homeo domain with others reveals a striking homology to the murine Hox 2.1 homeo domain whose encoding sequences are located on chromosome 11 (Hart et al. 1985; Hauser et al. 1985; Jackson et al. 1985). Although the two homeo boxes are $83.6 \%$ homologous in nucleotide sequence, their amino acid sequences are identical (for Hox 2.1 sequence, see Hauser et al. 1985). This perfect match extends six amino acids past the $3^{\prime}$ end of the homeo box and represents 66 amino acids of uninterrupted homology. Both homeo domains are positioned 16 amino acids from their respective carboxyl termini, with 12 of these 16 residues shared. The homology ends abruptly 3 ' to the proteincoding sequences. In the Hox 1 locus, the Hox 1.3 homeo domain shares $85.3 \%$ amino acid residue homology with Hox 1.1 (Colberg-Poley et al. 1985a), 88.5\% with Hox 1.2 (Colberg-Poley et al. 1985b), $88.5 \%$ with Hox 1.4 (Duboule et al. 1986), and $75.4 \%$ homology with Hox 1.5 (McGinnis et al. 1985).

Comparison of the predicted Hox 1.3 protein-encoding sequences to other homeo box genes reveals two regions $5^{\prime}$ to the homeo box that share homology with other domain proteins. The Hox 1.3 amino terminus is homologous to the amino terminus of the human HHO.cl3 protein (Mavilio et al. 1986). Seven of the first eight aminoterminal residues of the Hox 1.3 protein are identical to amino-terminal residues found in the predicted human protein (Fig. 1). The 255 -amino-acid HHO.c13 protein is also rich in serine, proline, and glycine amino acid residues. The two homeo domains share $90 \%$ homology. The second region of partial conservation identified from these comparisons is located at the $3^{\prime}$ end of the 
upstream exon, adjacent to the homeo box exon. The core sequence $\mathrm{TA}(\mathrm{C} / \mathrm{T}) \mathrm{CCCTGGATG}$, encoding amino acid residues Tyr-Pro-Trp-Met, positioned 21 bp upstream from the $3^{\prime}$ end of the first exon in $\operatorname{Hox} 1.3$ (Fig. 1 ) is also in a similar location in other homeo box genes [human, HHO.c13 (Mavilio et al. 1986); Xenopus, Xhoxl-A (Harvey et al. 1986); Drosophila Antp (Schneuwly et al. 1986); Deformed (Laughon et al. 1985)]. At present, it is unclear whether this region is required at the nucleotide level (e.g., RNA processing) or represents a functional domain in the protein.

The trinucleotide repeats, $\mathrm{CA}(\mathrm{G} / \mathrm{C})$ or $\mathrm{GA} / \mathrm{G} / \mathrm{A})$ repeats encoding polyglutamine and polyglutamic acid, respectively, found in the protein-coding sequences of several Drosophila and murine homeo box genes /ColbergPoley et al. 1985b; Regulski et al. 1985), are not present in the Hox 1.3 sequence.

\section{Expression of the murine Hox 1.3 gene}

We have analyzed the expression of murine Hox 1.3 transcripts by Northern blots, using poly $(\mathrm{A}){ }^{+}$RNA isolated from $B A L B / c$ mouse tissues of different stages of embryonic development, as well as adult tissues (Figs. 3 and 4). To avoid hybridization of mRNA encoding other homeo box proteins, the cDNA probes were derived from DNA sequences either $5^{\prime}$ or $3^{\prime}$ to the homeo box. Both probes identified the same sized transcripts in Northern blot analysis performed at high stringency. The most abundant Hox 1.3 transcript $(\sim 1.85 \mathrm{~kb})$ was detected in whole embryos after 9 days gestation. RNA isolated from 7.5-day gestation embryos contained levels of the Hox 1.3 transcript that were just barely detectable under the conditions we employ. Poly $(\mathrm{A})^{+}$RNAs, isolated from the heads, spinal columns, or bodies of 17-day gestation embryos, all contained the major Hox 1.3 transcript (Fig. 3), with the spinal column having the highest concentration. Northern analysis of 16-week postnatal adult liver, kidney, ovary, testis, spinal cord, and brain poly $(A)+$ RNA demonstrated that the major transcript was present at low levels in these tissues, with the greatest abundance observed in the spinal cord (Fig. 4). The relative intensities of the bands in Figures 3 and 4 cannot be compared directly since 10 times more mRNA was used in the adult Northern blot than in the embryo Northern, and the exposure time was much longer in the case of the adult Northern blot. Our cDNA probes hybridized to additional less abundant transcripts in both embryonic and adult Northern blots. Long-exposure autoradiographs of the embryonic and adult Northern blots demonstrated that these larger $(\sim 4,8$, and $9 \mathrm{~kb})$ transcripts were present in those poly $(\mathrm{A})^{+}$ RNA preparations that contained the major transcript of approximately $1.85 \mathrm{~kb}$. As shown in Figure 4, the adult liver, kidney, and ovary contained the greatest abundance of the minor transcripts among the adult tissues surveyed.

The Hox 1.3 gene specifies a protein found in the nuclei of nonconfluent cultured cells

To examine the expression and localization of the Hox 1.3 protein, two antisera specific to the $\operatorname{Hox} 1.3$ protein

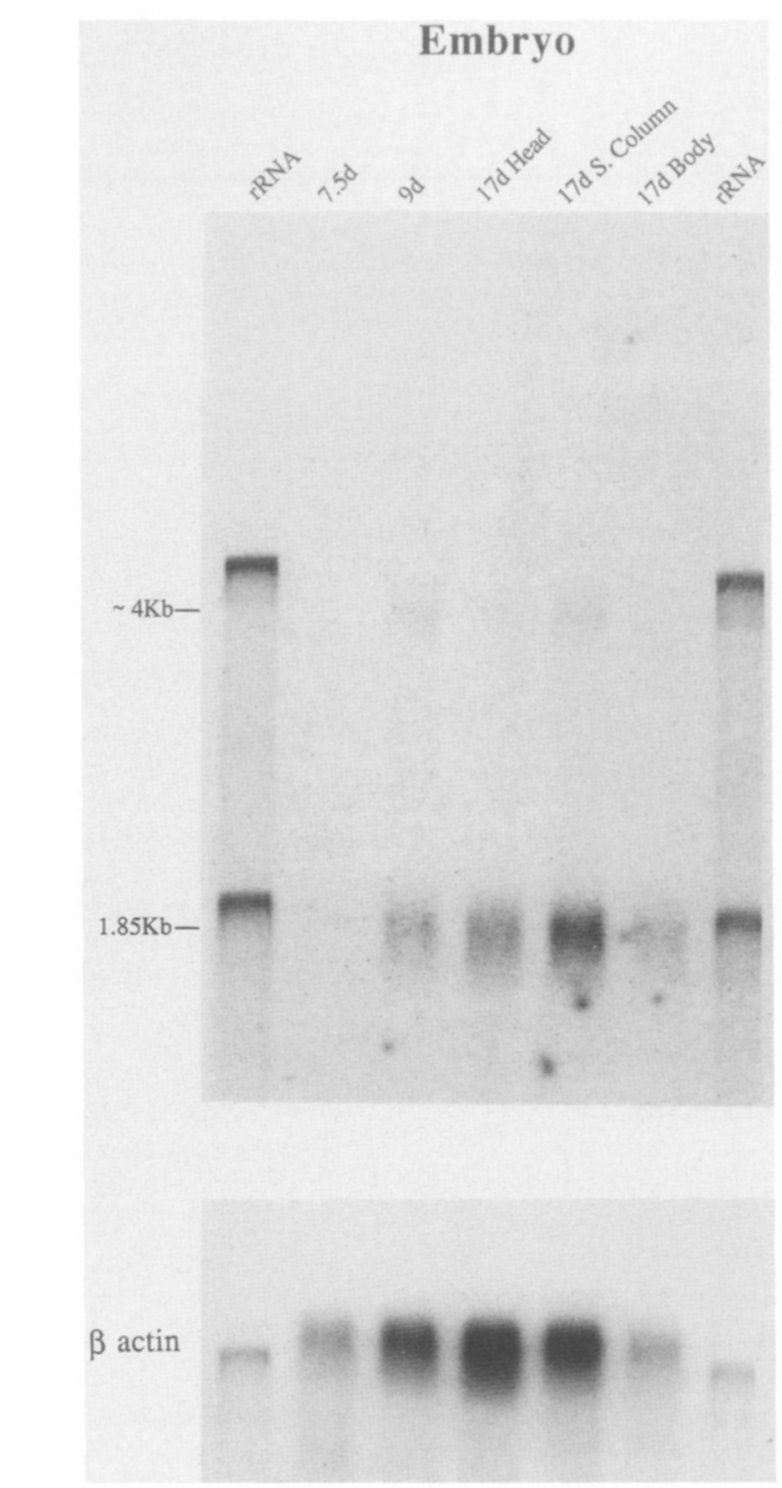

Figure 3. Expression of the Hox 1.3 gene in mouse embryos. Northern blot analysis of embryonic transcripts. Autoradiographic patterns of $1 \mu \mathrm{g}$ of poly(A)-selected RNA isolated from 7.5day total embryo, 9-day total embryo, and 17-day gestation RNA from head, spinal column, and carcass were electrophoresed through a formaldehyde-agarose gel, transferred to a nylon membrane, and hybridized under stringent conditions to random primer ${ }^{32} \mathrm{P}$-labeled probe 3 (Fig. 2). ${ }^{14} \mathrm{C}$-Labeled HeLa cell $18 \mathrm{~S}$ and $28 \mathrm{~S}$ rRNA standards were included for size determinations. Autoradiograph exposure was 3 days. To demonstrate message integrity, the blots were rehybridized to a $\mathrm{B}$ actin probe (see Experimental procedures).

were prepared. Synthetic $\left(20^{\prime}\right.$-mers), corresponding to amino acid residues 53-72 (peptide A) and 173-192 (peptide B) of the predicted protein (Fig. 1) were synthesized by the Merrifield solid-phase technique (Merrifield and Barany 1980). Both peptides represent portions of the protein that are amino-terminal to the homeo domain. Antisera recovered from rabbits immunized with either peptide A or B coupled to keyhole limpet hemo- 


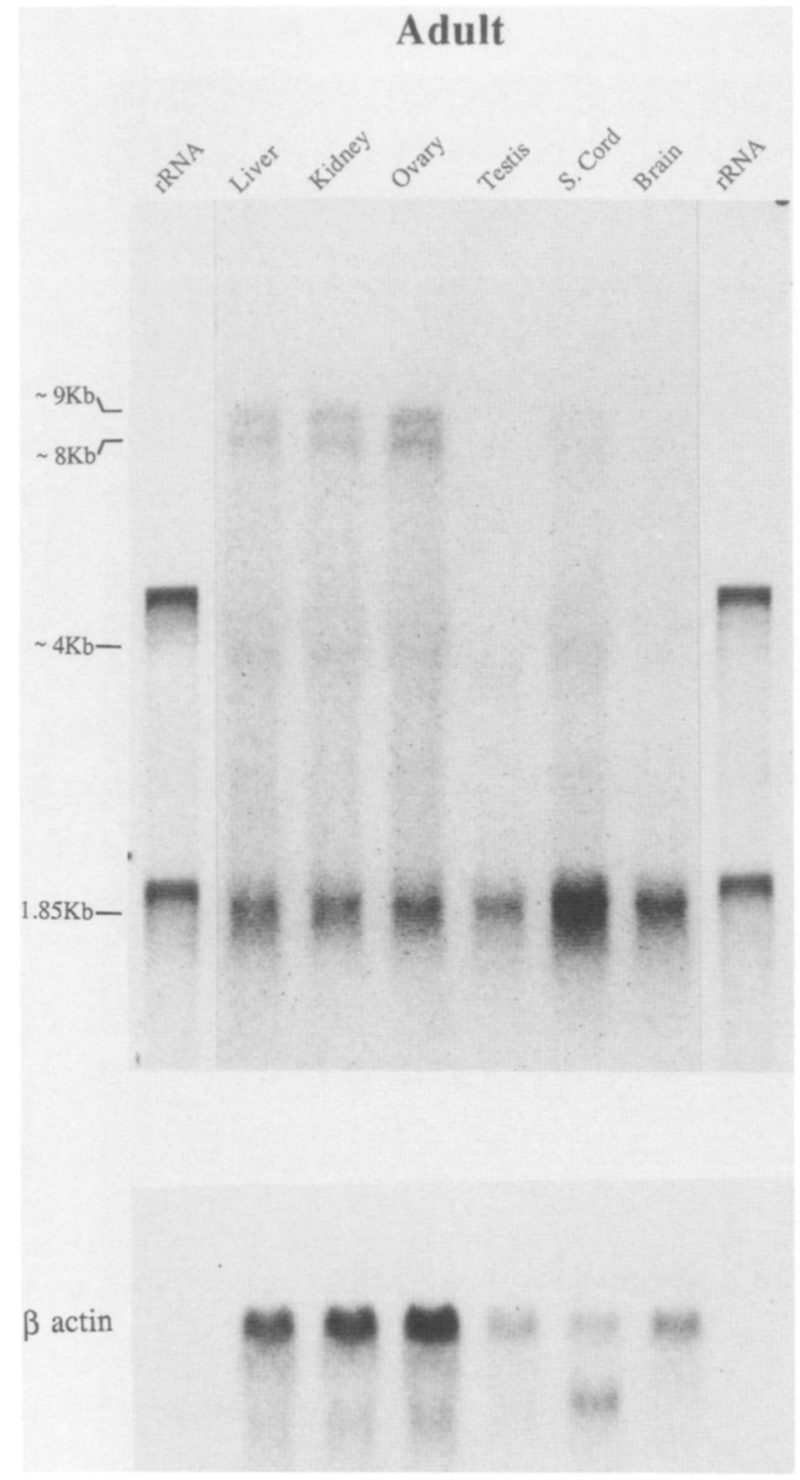

Figure 4. Northern analysis of Hox 1.3 expression in adult tissues. Autoradiographic patterns of $10 \mu \mathrm{g}$ of poly(A)-selected RNA isolated from adult liver, kidney, ovary, testis, spinal cord, and brain, processed and probed as in Fig. 3. Exposure time was 1 week. (Note that the rRNA standard lanes were taken from a 3-day exposure of the same blot.) To demonstrate message integrity, the blots were rehybridized to a B-actin probe (see Experimental procedures).

cyanin $(\mathrm{KLH})$ were employed in the immunolocalization and immunoblot experiments described below.

The presence of the Hox 1.3 gene transcripts in a variety of adult and embryonic tissues prompted us to examine whether cultured cells expressed the gene. Embryonic fibroblasts derived from 16-day gestation BALB/ c embryos were grown on glass chamber slides and examined by indirect immunofluorescence. The results of these studies are summarized in Figure 5. The nuclei and perinuclear cytoplasmic regions of nonconfluent cells (cells with few or no cell-cell contacts) showed flu- orescence (Fig. 5a). In areas of the same culture where cells were confluent and had many cell-cell contacts, the nuclei did not fluoresce (Fig. 5b). Cells with weak nuclear fluorescence were observed in regions of intermediate cell density and, in general, the intensity of nuclear fluorescence appeared to be related to the degree of cell-cell contact or growth rate. Independent of the intensity of the nuclear fluorescence, the nucleoli and/or heterochromatic regions of the nuclei did not stain. The pattern of immunofluorescence was the same whether antisera raised against peptide A or B were employed (data not shown). If the antisera were pretreated with the specific peptide used to raise them, the fluorescence was abolished. These controls, one of which is shown in Figure $5 \mathrm{c}$, demonstrate that the antibodies responsible for the immunofluorescence are those that recognize the epitopes present in peptides A or B. Antiserum dilutions containing the unrelated peptide (e.g., peptide B with antiserum A) had no effect on the immunofluorescent signal. Furthermore, the fact that the same pattern of fluorescence was obtained with both antisera makes it very likely that the Hox 1.3 protein itself, not a protein sharing an epitope with it, was responsible for the observed fluorescence. During the course of these experiments, the second region of partial conservation between various proteins containing homeo domains was identified (amino acid residues 176-180; Fig. 1). This pentapeptide is contained in the B peptide, and the possibility exists that antibody raised against this peptide might cross-react with other murine homeo box domain proteins. Consequently, we selected the antiserum specific for peptide $\mathrm{A}$ for the remaining immunolocalization and immunoblot experiments.

The rapidity with which confluent cells not expressing the Hox 1.3 protein can accumulate substantial amounts of it in their nuclei was investigated with "wounded" monolayers of cultured cells. Embryonic fibroblasts were grown to confluency on glass slides, and portions of the monolayer were then scraped away with a sterile razor blade. The monolayer scarring produced areas of high cell density adjacent to clearings free of cells. The wounded monolayers were cultured under standard conditions for different times before being processed for immunofluorescence identification of the Hox 1.3 protein. As expected, the nuclei of cells in confluent regions had little fluorescent staining whereas cells that had migrated into the clearing showed intense fluorescent staining (Fig. 5d). The Hox 1.3 protein could be detected in border cell nuclei as early as $30 \mathrm{~min}$ after the wounding. In regions of transitions between high and low cell density, both fluorescent patterns were observed. In areas of intermediate cell density, cells with negative nuclei frequently had intense perinuclear staining. Again, the gradient of fluorescence appears to reflect the degree of cell-cell contact or growth rate.

The results described above were obtained not only with primary embryonic cell cultures but also with clonal cell lines like the NIH-3T3 cell line. The nuclear accumulation, the changes in the relative abundance, and the apparent molecular weight of the Hox 1.3 protein were further investigated with immunoblots of $3 \mathrm{~T} 3$ 


\section{Odenwald et al.}
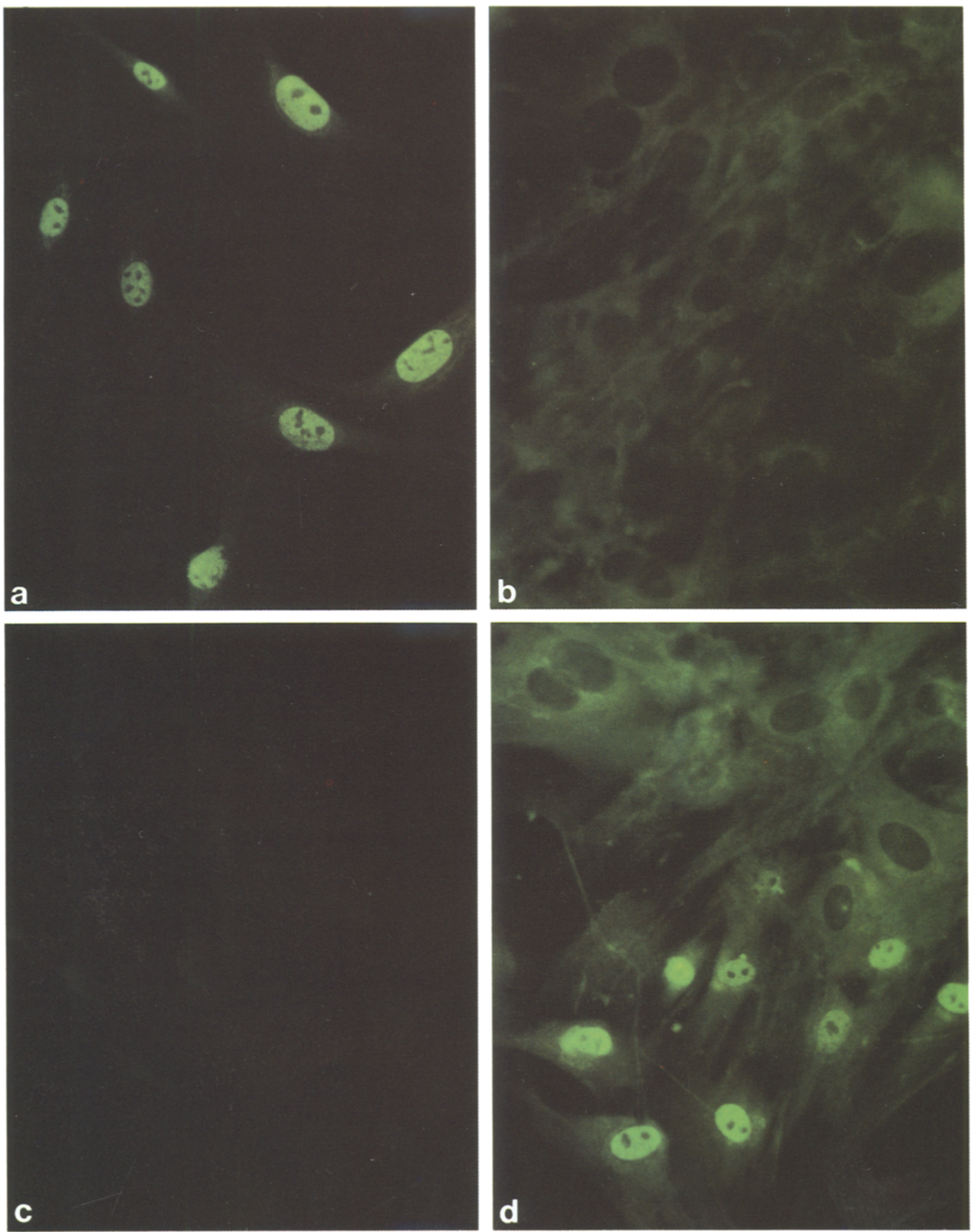

Figure 5. Immunofluorescent staining of primary mouse embryonic fibroblasts using anti-Hox 1.3 antisera. (a) Nuclear localization of Hox 1.3 protein in nonconfluent cells. (Note the exclusion of fluorescence from the nucleoli and/or heterochromatic nuclear regions.) (b) Immunostaining profile of a high cell density area from the same culture as shown in $a$. (Note the absence of nuclear fluorescence and the diffuse cytoplasmic staining.) (c) Peptide completion control on semiconfluent cells demonstrating specificity of staining. (d) Immunostaining of a wounded monolayer $18 \mathrm{hr}$ after scarring. Cells in the lower half of the micrograph have migrated into the clearing away from the high cell density monolayer (upper half). Note the gradient of nuclear fluorescence. Magnifications: $a$ and $b, 280 \times ; c, 80 \times ; d, 220 \times$. 
cells. Nuclei were prepared from both stationary-phase (confluent) and growing (nonconfluent) 3T3 cell cultures. Sonicated extracts of these crude nuclear preparations were fractionated by SDS gel electrophoresis, and the separated proteins were transferred to nitrocellulose membranes. Immunostaining of transfers with anti-peptide A antisera (using an anti-rabbit IgG-conjugated phosphatase reporter system/ revealed a major protein in the nonconfluent extract of approximately $32 \mathrm{kD}$ (Fig. 6 , lane 3$)$. Additional less abundant species $(\sim 33$ to $35 \mathrm{kD})$ were also detected in this extract. In the nuclearenriched preparations from the confluent culture (Fig. 6, lane 4), a protein with the same electrophoretic mobility as the nonconfluent major $32-\mathrm{kD}$ protein was identified, but its relative abundance was approximately five times less. The immunostaining of these proteins was abolished if the antisera was pretreated with peptide A (Fig. 6, lanes 5 and 6). Anti-peptide B antisera yielded similar results, except that some additional faint bands of higher molecular weight were visible (data not shown). This result is consistent with the lower specificity of this reagent since it is directed at a conserved sequence.

The apparent molecular weight of the major form of the Hox 1.3 protein is greater than that predicted from the sequence shown in Figure 1. The reason for this discrepancy is obscure at present, but several explanations are possible. The Hox 1.3 protein has an exceptionally high serine content, a characteristic associated frequently with overestimates of the molecular weight by

1

$$
2
$$

3

4

5

6

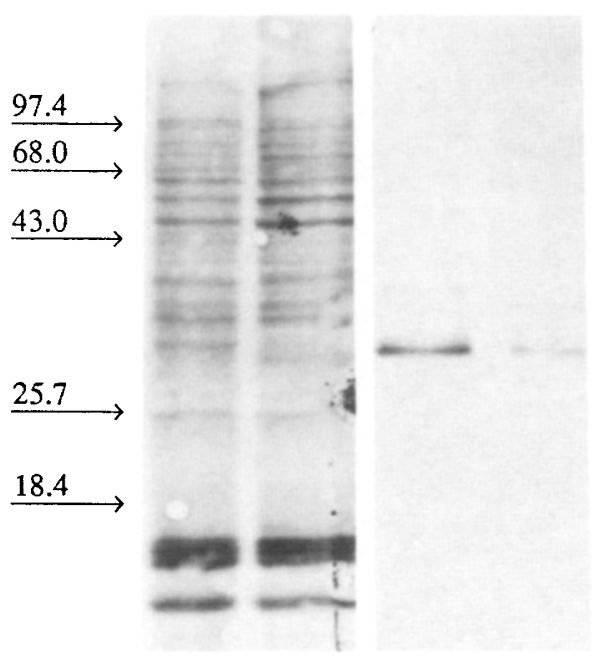

Figure 6. Immunoblot analysis of Hox 1.3 protein in crude nuclear extracts of confluent and nonconfluent cultured NIH-3T3 cells. Proteins from crude nuclear extracts of nonconfluent (lanes 1, 3, and 5) and confluent (lanes 2, 4, and 6) cultures were resolved on a $12.5 \%$ SDS polyacrylamide gel and electroblotted onto nitrocellulose. (Lanes 1 and 2) Blotted proteins stained with Amido Black; (lanes 3 and 4) blotted proteins probed with anti-peptide A antisera; (lanes 5 and 6$)$ peptide-blocking control probed with anti-peptide $\mathrm{A}$ antisera diluted in buffer containing peptide A $(200 \mu \mathrm{g} / \mathrm{ml})$. $\left(\rightarrow \mid\right.$ Positions of blotted ${ }^{14} \mathrm{C}$-labeled protein standards (Bethesda Research Labs).
SDS gel electrophoresis (Gallione et al. 1981; Kaufmann et al. 1984). The high serine content of the Hox 1.3, as well as the multiple forms of the protein, suggests that posttranslational modification (e.g., phosphorylation) may be a contributing factor to this discrepancy. Final resolution of this issue must await a detailed analysis of the protein.

In parallel experiments, Northern analyses of Hox 1.3 transcripts were studied using poly $(\mathrm{A})^{+} \mathrm{RNA}$ isolated from confluent and nonconfluent cultures. Comparison of the relative abundances of the Hox 1.3 message in these two RNA preparations (Fig. 7) showed that nonconfluent cells contained approximately 10- to 15 -fold more Hox 1.3 transcripts than the confluent cells [ $2 \mu \mathrm{g}$ of poly $(\mathrm{A})^{+}$RNA nonconfluent cell contains two to three times more transcript than that found in $10 \mu \mathrm{g}$ of poly $(\mathrm{A})^{+}$RNA from confluent cells]. These data suggest that changes in the rate of transcription and/or Hox 1.3 mRNA stability account for some of the changes in the Hox 1.3 protein abundances seen between growing and mitotically quiescent cultured cells.

\section{Postmitotic neurons in the adult CNS express the Hox 1.3 protein}

Northern analysis of adult tissues indicated that the CNS contained the highest steady-state level of the major Hox 1.3 transcript. At this particular stage of development, the CNS contains large numbers of mitotically quiescent cells. To determine if the in vitro correlation to growth (observed in the cultured cells) applied to an in vivo pattern of expression, we identified the Hox 1.3 protein-expressing cell types in the CNS by immunolocalization. Sections of brain and spinal cord of 16week, postnatal BALB/c mice were stained with antisera to peptide A with the peroxidase-antiperoxidase technique (Sternberger 1979). Immunoreactive neuronal nuclei are present in gray matter of all regions examined, including spinal cord, brain stem, cerebellum, diencephalon, and cerebrum. In contrast, immunoreactive nuclei are absent from white matter structures, such as the corpus callosum and the cerebellar and spinal cord white matter. Many neurons also exhibit cytoplasmic immunoreactivity, as described below.

In the hippocampal formation, the granule cell layer and the pyramidal cell layer exhibit strong staining (Fig. $8 \mathrm{a})$, which is abolished when antisera are blocked with specific peptide (Fig. $8 \mathrm{~b}$ ). This staining is present in the nuclei and cell bodies of pyramidal cells and extends into their apical dendrites (Fig. 8c). In addition, scattered cells, presumably basket neurons, in the layers superficial (striatum oriens) and deep (striatum radium) to the pyramidal cells are also immunostained. In the cerebellum, Purkinje cells, which separate the molecular layer from the inner granular layer of the cerebellar cortex, show intense staining (Fig. 8d). This staining is also abolished when antibody is pretreated with specific peptide (Fig. 8e). Higher magnification of the three cortical layers (Fig. 8f) reveals positive staining in the molecular layer stellate and basket neurons, and staining of the dendritic trunks and perikarya of the Purkinje neurons. The granular layer is largely unstained, indicating 


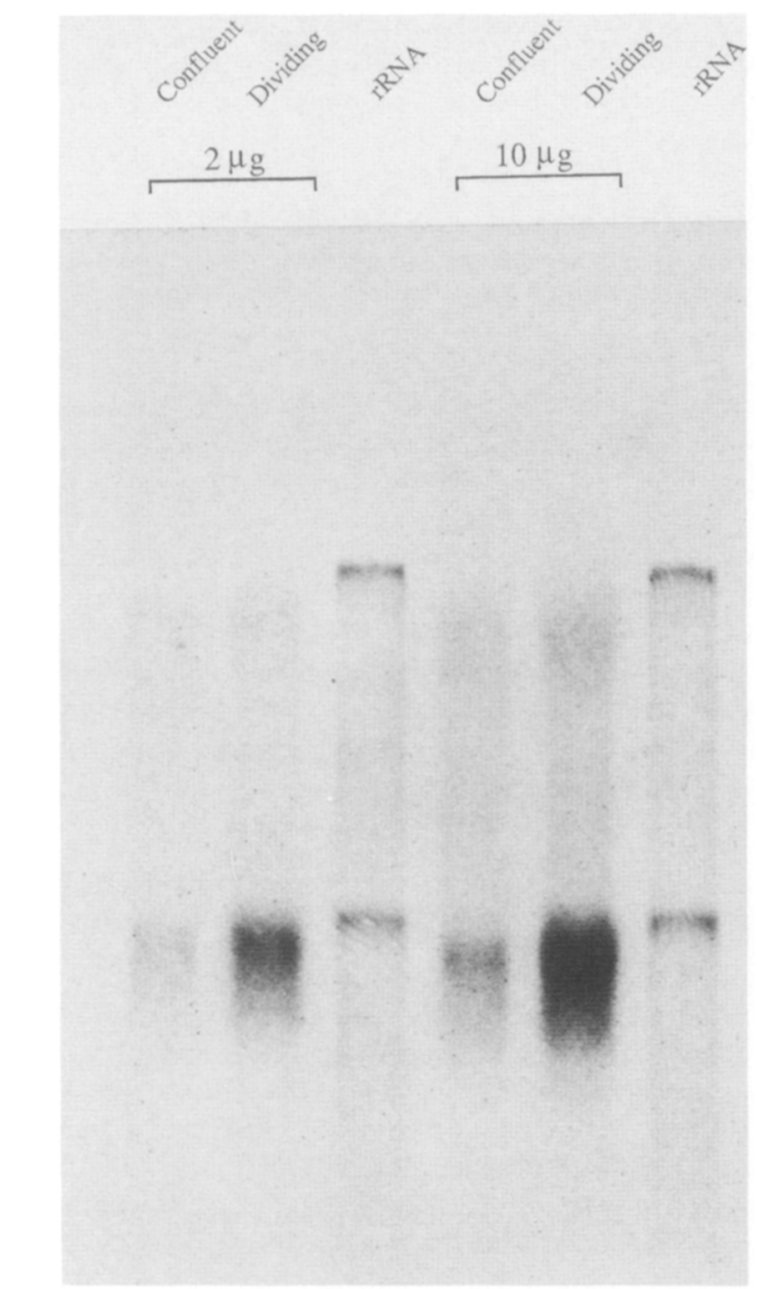

Figure 7. Steady-state $\operatorname{Hox} 1.3$ message levels in confluent and nonconfluent cultured NIH-3T3 cells. Northern blot of either 2 $\mu \mathrm{g}$ or $10 \mu \mathrm{g}$ of poly(A) ${ }^{+}$selected RNA isolated from high-celldensity confluent monolayers or low-cell-density nonconfluent cultures grown under identical conditions. The blot was probed with the 3 '-untranslated portion of the Hox $1.3 \mathrm{cDNA}$ (probe 3, Fig. 2) under stringent conditions (see Experimental procedures). Autoradiographic exposure time was 3 days.

that granule neurons do not contain substantial amounts of the Hox 1.3 protein. However, scattered large cells within the granular layer, presumably Golgi II interneurons, do stain distinctly (Fig. 8f).

Immunostaining of the cerebral cortex reveals cells containing Hox 1.3 protein in all cortical layers (Fig. $8 \mathrm{~g}, \mathrm{~h})$. Pyramidal cells exhibit both nuclear and cytoplasmic staining, revealing the characteristic triangular shape of their somas and the initial course of their apical dendrites. Throughout the cortex are unidentified cells that appear to have little or no Hox 1.3 protein. Glycerol-mounted cortex sections viewed under conditions that illuminate nuclei as refractile bodies show both immunostained and unstained nuclei (arrows) in the cortex (Fig. 8h). Many unstained nuclei and cell bodies are large and may belong to neurons.

Immunolocalization performed on transverse sections of the lower cervical portion of the spinal cord demonstrate that the nuclei of large neurons located in the ventral horn (Lamina IX), presumed to be somatic motor neurons, contain Hox 1.3 protein (Fig. 8i).

\section{Discussion}

The Hox 1.3 gene described here was identified previously by Colberg-Poley et al. (1985b) as the $\mathrm{m}-2$ homeo box. The gene is part of the Hox 1 cluster, a $70-\mathrm{kbp}$ region located on bands $\mathrm{B} 3 \rightarrow \mathrm{C}$ of chromosome 6 , which contains six homeo box sequences (Colberg-Poley et al. 1985b; Búcan et al. 1986; Duboule et al. 1986). Northern blot analysis of Hox 1.3 expression demonstrated that the $1.85-\mathrm{kb}$ transcript was always the most abundant message and the 4-, 8-, and $9-\mathrm{kb}$ forms were present at a much lower level, irrespective of the tissue examined. The $3^{\prime}$ end of the major $1.85-\mathrm{kb}$ transcript is likely to be defined by the cDNA clone since it contains both the polyadenylation signal and a portion of the poly $(\mathrm{A})$ tail. Comparison of the cDNA and genomic sequences reveals two exons separated by a 960 -bp intron. * The $5^{\prime}$ end of the major transcript has not been positively identified but is estimated to lie at the consensus sequence for a cap site (position -90, Fig. 1). Northern analysis with synthetic oligonucleotide probes that hybridize to sequences flanking this consensus capping site indicates that the major $1.85-\mathrm{kb}$ transcript does not extend $5^{\prime}$ to the suggested cap site (Jim Garbern, unpubl.). Initiation at this site and polyadenylation where indicated by the cDNA would yield a spliced polyadenylated transcript of approximately $1.85 \mathrm{~kb}$. Initiation of protein synthesis at the first AUG of this transcript yields a protein with an amino terminus that shares homology with the amino termini of two other vertebrate proteins containing homeo domains: the human HHO.c13 (Mavilio et al. 1986) and Xenopus Xhoxl-A (Harvey et al. 1986). Consequently, it is likely that the sequences shown in Figure 1 contain all of the protein-encoding sequences present in the major Hox 1.3 transcript.

The uninterrupted perfect homology of 66 amino acid residues between the predicted Hox 1.3 and Hox 2.1 homeo domains and their identical positions from their carboxyl termini suggest that the two domains perform similar, if not identical, functions. Excluding interspecies cognates [e.g., the murine and human Hox 2.1 [Hart et al. 1985; Hauser et al. 1985)], the perfect match between Hox 1.3 and Hox 2.1 homeo domains has not been observed between other domains, particularly between homeo domains from the same species. The significance of the Hox 1.3-Hox 2.1 interloci homology is further enhanced when the genomic maps of the Hox 1 locus [Colberg-Poley et al. 1985b (Fig. 1); Duboule et al. 1986 (Fig. 2)] and Hox 2 locus [Hart et al. 1985 (Fig. 1)] are aligned at the Hox 1.3 and Hox 2.1 boxes. The genomic spacing between $\operatorname{Hox} 2.3$, Hox 2.2, and Hox 2.1 matches the separations between the first three boxes of the Hox 1 locus. In light of the homology that exists between Hox 1.3 and Hox 2.1 domains and the homeo box

\footnotetext{
*The sequence of the intron has been deposited with GenBank and is not reported here.
} 
alignment between the Hox 1 and Hox 2 loci, these two genomic regions may have arisen from a duplication event followed by divergence. The predicted duplication is not without precedent. Elements of the Drosophila Antennapedia Complex are thought to have given rise to a precursor of the Bithorax Complex via duplication and divergence (Lewis 1978; McGinnis et al. 1984c).

Northern blot analysis of the Hox 1.3 transcripts revealed, as expected, that this homeo box gene was maximally expressed during embryonic development. This expression is consistent with the notion that this class of genes is likely to play an important role in pattern formation during embryogenesis. However, the Northern blots also revealed that the Hox 1.3 gene is expressed at a lesser level in many different adult tissues with endo-, ecto-, or mesodermal origins long after pattern formation, development, and growth are complete. Although the appearance of transcripts in adult tissue has been reported for other murine homeo box genes (see introductory section), the significance of this consistent observation is yet to be established.

Many genes in the Hox 1 cluster are expressed as multiple transcripts whose relative abundances differ in different tissues (see references listed in Fig. 2). The larger transcripts identified by our Hox 1.3 probes (4, 8, and 9 $\mathrm{kb}$ ) are unexplained at this point since we do not have information about their initiation or termination sites. We have ascertained that they contain sequences from both exons of the Hox 1.3 gene and are polyadenylated. It is unlikely that even the smallest of them is an unspliced precursor of the $1.85-\mathrm{kb}$ transcript, since it is much larger than the $2.8 \mathrm{~kb}$ predicted for that species. Colberg-Poley et al. (1985b) observed a transcript of approximately $8 \mathrm{~kb}$ that carried Hox 1.2 information, and the proximity of the Hox 1.2 and Hox 1.3 genes $(\sim 5 \mathrm{kbp})$ suggests that this transcript may also contain Hox 1.3 information and may correspond to the 8-kb Hox 1.3 transcript detected by our cDNA probes. Synthetic oligonucleotide probes that hybridize to sequences $5^{\prime}$ to the suggested Hox 1.3 cap site identify the larger, less abundant transcripts but not the major 1.85-kb Hox 1.3 message (Jim Garbern, unpubl.).

The immune reagents that we have generated were used to investigate the expression of the Hox 1.3 gene in cultured cells and in adult tissues. Cultured cells, whether primary mouse embryo or $3 \mathrm{~T} 3$ fibroblasts, express the Hox 1.3 protein in their nuclei when they are mitotically active or, at least, not contact inhibited. Upon reaching stationary phase or confluency, the amount of the nuclear protein and cellular mRNA detected by our probes diminishes markedly. Within 30 min of the removal of the contact inhibition by wounding, the amount of the Hox 1.3 protein in the nuclei of cells at the edge of the wound increased to detectable levels. The perinuclear cytoplasmic staining observed in cells that had little or no nuclear fluorescence (cells with many cell-cell contacts) and the detection of reduced amounts of Hox 1.3 protein in the crude nuclear extracts from high cell density confluent cultures suggest that the Hox 1.3 protein may be present in these cells, but its nuclear entry is blocked. It is possible that some of the diminished immunostaining observed in confluent cells might be attributable to post-translational modification of the protein. Anti-peptide antibodies recognize only a limited portion of the protein, and those epitopes may be unavailable to the immune reagents after modification. However, the fact that the Hox 1.3 mRNA was also diminished in mitotically quiescent fibroblasts suggests that at least some of the regulation is exerted at the level of transcription or mRNA stability.

The results described here suggest that cell-cell contacts may play a role in the regulation of this homeo box gene. Cell-density-dependent contact inhibition of cultured cell proliferation has been shown recently by Wieser and Oesch (1986) to be mediated by specific cell-cell interactions via plasma membrane glycoproteins. If the expression of homeo box genes is influenced by positional information, the communication of some of these positional cues may be via cell-surface glycoprotein. Further analysis, such as the response to plasma membrane glycoproteins, extracellular matrices, and growth factors, is required to elucidate those factors that modulate the expression of Hox 1.3.

The relationship between growth rate and/or cell-cell contact in cultured cells and the level of the Hox 1.3 in their nuclei was a consistent observation. Nevertheless, attempts to extend the correlation with growth rate to the in vivo situation have not been successful thus far. For example, tissue sections of the cerebellar external granular layer of 8-day-old mice show no demonstrable amounts of the Hox 1.3 protein, although this region of the cerebellum is rich in mitotic neurons /data not shown). The correlation of the appearance of the Hox 1.3 protein in the nuclei and growth rate is not a general one and may only apply to certain cell types. Indeed, the converse of this relationship - the appearance of the Hox 1.3 protein in postmitotic, fully differentiated cells - has been observed in the CNS of the adult mouse. As shown in Figure 8, particular subsets of neurons contain the Hox 1.3 protein. Hippocampal pyramidal cells and cerebellar Purkinje cells both clearly contain substantial amounts of the protein and yet are known to be mitotically inactive cells. The expression of Hox 1.3 is not a general property shared by all neurons. This is best appreciated in the sections of the cerebellum, a structure containing more than half of the neurons of the entire brain. Here, only the Purkinje, basket, stellate, and putative Golgi type-II neurons stain positively for the Hox 1.3 protein. The granular layer of the cerebellum is composed of densely packed neuron cell bodies, yet shows very little immunostaining. This differential expression is also revealed in the glycerol mount sections of the cerebral cortex where Hox 1.3-positive and Hox 1.3-negative nuclei are both defined clearly (Fig. 8h).

Our observations concerning the expression of $H o x$ 1.3 both in vivo and in vitro suggest that expression may not be related directly to mitotic activity but, rather, a response to extracellular cues, perhaps those derived from specific cell-cell contacts. The complex pattern of 
Odenwald et al.
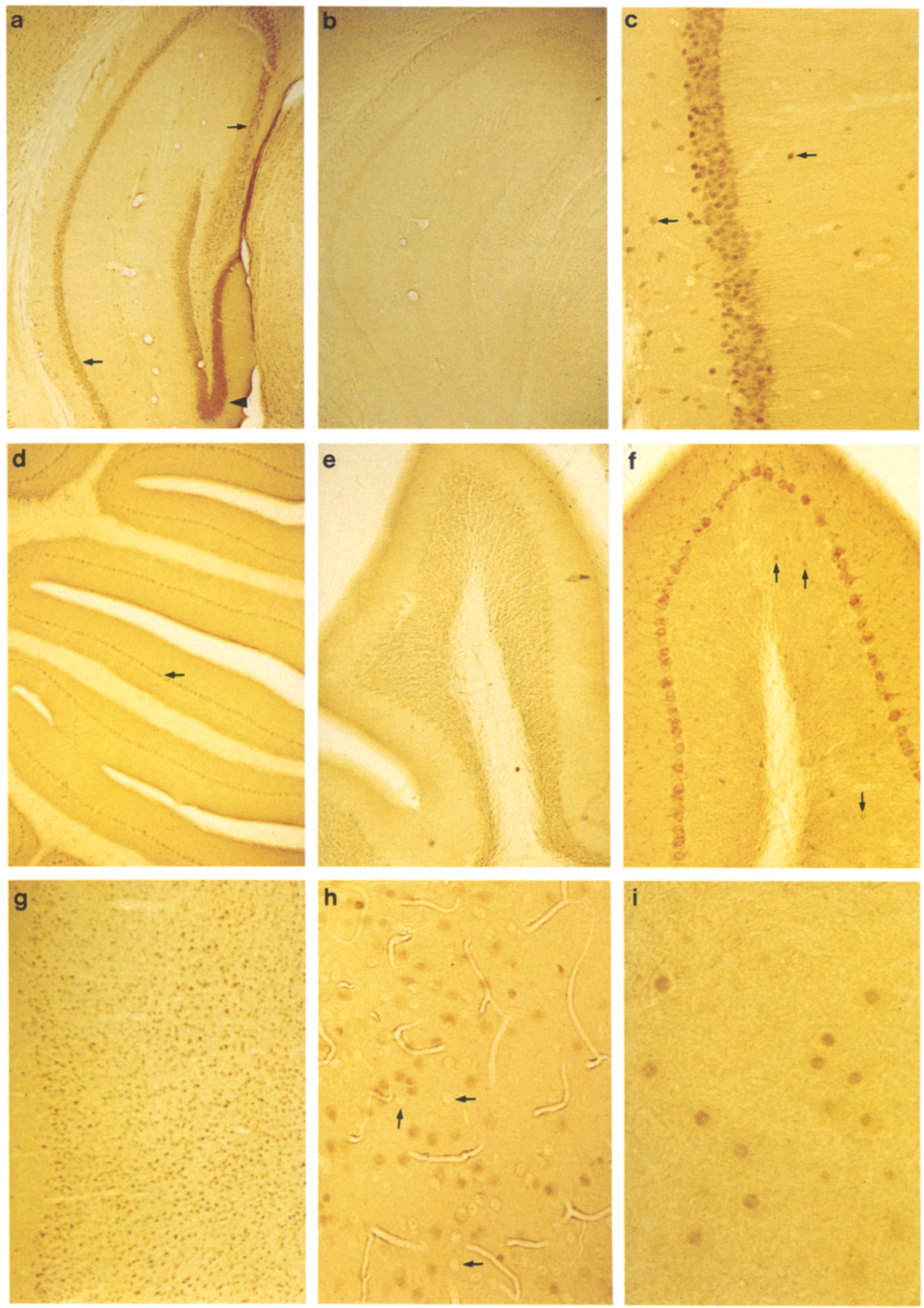

Figure 8. (See facing page for legend.) 
Hox 1.3 expression in embryo and adult mice indicates that the Hox 1.3 protein plays a role in many cell types. Although the functions of this nuclear protein are not known, the diversity of cell types expressing the protein suggests that they may be numerous.

\section{Experimental procedures}

\section{Cloning and sequencing}

Standard screening procedures (Maniatis et al. 1982), with a nick-translated ${ }^{32} \mathrm{P}$-labeled BamHI-PvuII 600-bp probe containing the Antp homeo box (Garber et al. 1983), were employed to screen [under conditions of reduced stringency (McGinnis et al. 1984a)] a $\lambda$ gtll cDNA library prepared from 18-day postnatal BALB/c mouse brain poly $\mid \mathrm{A})^{+} \mathrm{RNA}$ (Kamholz et al. 1986). Restriction endonuclease fragments isolated from the c $\lambda \mathrm{mb}-1$ cDNA were subcloned into pUC18 or pUC19 plasmid vectors. These subclones (shown as probes 1,2 , and 3 in Fig. 2) were, in turn, used as probes in the isolation of overlapping genomic clones from an EMBL3 mouse genomic library. The cDNA probes were labeled with ${ }^{32}$ P-labeled dCTP by random priming, using an oligolabeling kit (Pharmacia). Genomic screening was performed under high-stringency hybridization conditions $5 \times \mathrm{SSC}, 50 \%$ formamide, $42^{\circ} \mathrm{C}$, with final washes in $0.1 \times \mathrm{SSC}, 0.1 \%$ SDS at $55^{\circ} \mathrm{C}$ for $\left.30 \mathrm{~min}\right)(1 \times$ $\mathrm{SSC}=0.15 \mathrm{M} \mathrm{NaCl}, 0.01 \mathrm{M} \mathrm{Na}$ citrate, $\mathrm{pH} 7.0$ ). Restriction endonuclease and Southern analysis of both cDNA and genomic clones were performed as described by Maniatis et al. (1982). Southern blots of the Hox 1 genomic clone $\lambda \mathrm{m}-6$ /Colberg-Poley et al. 1985a), double-digested with EcoRI and SacI, were probed under high-stringency conditions with random primer ${ }^{32} \mathrm{P}-\mathrm{la}$ beled genomic probes to demonstrate that the genomic clones represented part of the Hox 1 locus. The four strands of the c $\lambda$ mb-1 cDNA and Hox 1.3 genomic DNA shown in Figure 1 were sequenced by the dideoxynucleotide chain-termination technique (Sanger et al. 1977) using M13 mpl8 or mpl9 vectors (Messing 1983) and either M13 universal primers or custom primers synthesized on an Applied Biosystems 380A DNA synthesizer.

\section{RNA isolation from embryos, adult tissues, and cultured cells}

$\mathrm{BALB} / \mathrm{c}$ females who had vaginal plugs the morning after a 12-hr mating period were selected, and this day was considered the first day of gestation. Embryos were removed from the uterus at 7.5, 9, and 17 days gestation, essentially as described by Hart et al. (1985). After removal of the placenta and surrounding membranes, the embryos or their dissected parts were quick-frozen in liquid nitrogen and stored at $-70^{\circ} \mathrm{C}$ until suffi- cient amounts were obtained for RNA extraction. Spinal columns were dissected from 17-day gestation embryos, as described by Awgulewitsch et al. (1986). Adult tissues, dissected from 16-week postnatal mice (killed by cervical dislocation), were frozen and stored as described above. Brains were separated from the spinal cord at the medulla oblongata. Confluent (mitotically quiescent) and nonconfluent (dividing) NIH-3T3 cells cultured on plastic petri dishes in Dulbecco's modified minimal essential medium (DMEM), supplemented with $10 \%$ fetal calf serum (FCS) and antibiotics, were rinsed with and collected in ice-cold phosphate-buffered saline (PBS). Total cellular RNA was isolated by the guanidinium isothiocyanate/cesium chloride method described by Maniatis et al. (1982). Embryos, tissues, or cultured cells were homogenized in ice-cold $4 \mathrm{M}$ guanidinium isothiocyanate lysis buffer at a tissue concentration of $300 \mathrm{mg} / \mathrm{ml}$ of lysis buffer. Homogenization was performed with an Ultra Turrax Tissuemizer (Janke and Kunkel), using an N8 blade at the highest speed for 45-90 sec. The remaining steps were performed as described, with the exception that the final cesium chloride concentration in the homogenate was $0.25 \mathrm{~g} / \mathrm{ml}$. Poly $\mid \mathrm{A})^{+}$RNA enrichment from the total RNA preparations was accomplished by one passage through oligo(dT)-cellulose (Collaborative Research) columns. RNA concentrations were determined by absorbance at $260 \mathrm{~nm}$.

\section{Northern blot analysis}

Poly $(\mathrm{A})+$ RNA preparations were electrophoresed through $2.2 \mathrm{M}$ formaldehyde $-1 \%$ agarose gels and transferred to Zeta Probe (Bio-Rad Labs) nylon membranes in $20 \times$ SSC, according to Maniatis et al. (1982). ${ }^{14} \mathrm{C}$-Labeled HeLa $18 \mathrm{~S}$ and $28 \mathrm{~S}$ rRNAs were included as size markers. After transfer, the membranes were baked in a vacuum oven $\left(80^{\circ} \mathrm{C}\right)$ for $1 \mathrm{hr}$ and prehybridized for $10 \mathrm{hr}$ at $42^{\circ} \mathrm{C}$ in $50 \%$ formamide, $5 \times$ Denhart's solution, $5 \times \operatorname{SSPE}(1 \times \operatorname{SSPE}=10 \mathrm{mM}$ sodium phosphate, $0.15 \mathrm{M} \mathrm{NaCl}$, $1 \mathrm{mM}$ EDTA, pH 7.4), $1 \%$ SDS, and $100 \mu \mathrm{g} / \mathrm{ml}$ denatured salmon sperm DNA. Denatured probes were mixed with fresh hybridization solution and hybridized at $42^{\circ} \mathrm{C}$ for $18-24 \mathrm{hr}$. The random primer-labeled probes had an approximate specific activity of $10^{9} \mathrm{cpm} / \mu \mathrm{g}$ and were used at a concentration of $10^{6}$ $\mathrm{cpm} / \mathrm{ml}$ of hybridization solution. Following hybridization, membranes were washed twice in $2 \times$ SSC, $0.1 \%$ SDS at room temperature for $15 \mathrm{~min}$, twice in $1 \times \mathrm{SSC}, 0.1 \% \mathrm{SDS}$ at room temperature for $15 \mathrm{~min}$, once in $0.2 \times \mathrm{SSC}, 0.1 \% \mathrm{SDS}$ at $68^{\circ} \mathrm{C}$ for $30 \mathrm{~min}$, and once in $0.1 \times \mathrm{SSC}, 0.1 \%$ SDS at $68^{\circ} \mathrm{C}$ for 30 min. Autoradiography was performed at $-70^{\circ} \mathrm{C}$ with the aid of intensifying screens. Hybridization probes were removed from the Zeta Probe membranes by washing in hybridization solution at $80^{\circ} \mathrm{C}$ for $1 \mathrm{hr}$. To demonstrate message integrity, Northern blots were rehybridized to a B-actin cDNA probe employing the hybridization and wash conditions described above.

Figure 8. Immunoperoxidase staining of the adult mouse CNS with anti-Hox 1.3 antisera. $(a-c)$ Coronal hippocampal sections. $(a)$ Arrows denote the Hox 1.3-positive pyramidal neurons of the regio superior and inferior fields. Immunostained granular neurons of the dentate gyrus are indicated by the arrowhead $(40 \times)$. (b) Peptide competition control of a serial section from the same hippocampus as in $a(40 \times) .(c)$ Higher magnification of the regio superior field shown in $a$. Arrows indicate immunostained basket neurons in the striatum oriens and radium $(200 \times)$. (d-f) Immunolocalization of Hox 1.3 protein in sagittal cerebellum sections. (d) Low-magnification view of cerebellar cortex showing immunopositive Purkinje neurons (arrow) $(40 \times)$. $(e)$ Peptide-blocking control $(180 \times)$. $(f)$ Highmagnification view of the immunostained cerebellar cortex showing the molecular layer, Purkinje cell layer, and granular layer of the gray matter. Note the immunostained molecular layer stellate neurons, Purkinje neurons, and granular layer Golgi type-II neurons (arrows). $(g$ and $h$ ) Localization of Hox 1.3 protein-containing cells in the cerebral neocortex. $(g)$ Immunopositive cells were observed in all cortical layers $(65 \times)$. (h) Glycerol-mounted neocortex sections, which reveal nuclei as refractal bodies, illustrate that not all nuclei contain $\operatorname{Hox} 1.3$ protein (arrows). Also note that the capillaries are illuminated by this mounting procedure $(250 \times)$. (i) Localization of the Hox 1.3 protein in the nuclei of spinal cord somatic motor neurons $(200 \times)$. 


\section{Peptide synthesis and antiserum production}

Synthetic peptides (20'-mers) shown in Figure 1 were synthesized by the Merrifield solid-phase technique (Merrifield and Barany 1980), with an Applied Biosystems 430A peptide synthesizer. Peptides were purified by high-pressure liquid chromotography, and the molecular weight and purity of each were confirmed by fast-atom-bombardment mass-spectrophotometry. Amino acid analysis performed on hydrolysis products of each peptide gave compositions consistent with the expected products. Peptides were coupled to KLH by two methods described by Richardson et al. (1985). Glutaraldehyde was used as the coupling agent for the first procedure. Peptide $(5 \mathrm{mg})$ and $\mathrm{KLH}$ ( $5 \mathrm{mg}$ ) were dissolved in $5 \mathrm{ml}$ of PBS; glutaraldehyde (electron microscopic grade) was added in small increments to a final concentration of $0.25 \%(\mathrm{vol} / \mathrm{vol})$ while mixing. After 30 min at room temperature, the peptide-KLH conjugate was dialyzed overnight at $4^{\circ} \mathrm{C}$ with two l-liter changes of PBS. The second method employed 1-ethyl-3-(3-dimethylaminopropyl) carbodimide (EDAC) as the coupling agent. Peptide ( $5 \mathrm{mg}$ ), $\mathrm{KLH}$ (5 mg), and EDAC $\left(5 \mathrm{mg}\right.$ ) were dissolved in $5 \mathrm{ml}$ of PBS at $4^{\circ} \mathrm{C}$. After an overnight incubation at $4^{\circ} \mathrm{C}$, the conjugate was dialyzed as described above. The two conjugates were pooled and stored at $-70^{\circ} \mathrm{C}$. Aliquots were thawed and emulsified in either Freund's complete or incomplete adjuvant $(1: 1 \mathrm{vol} / \mathrm{vol})$. Virgin female New Zealand white rabbits were injected subcutaneously along their backs with approximately $0.2 \mathrm{mg}$ of peptide$\mathrm{KLH}$ conjugate (in complete adjuvant) at each of 10 sites. The injection protocol was repeated $3,5,9,13$, and 17 weeks after the initial inoculation with conjugate emulsified in incomplete adjuvant. Rabbits were bled $(25-30 \mathrm{ml}$ of blood via ear veins) 3 weeks after each inoculation starting with the second boost. Antisera were monitored for the presence of peptide-specific IgG by the enzyme-linked immunoadsorption assay (ELISA), according to the protocol described by Richardson et al. (1985). When the ELISA titer reached 30,000 (defined as the reciprocal of the antibody dilution that yielded $50 \%$ of the maximum color development), the antiserum was employed in the immunolocalization and immunoblot experiments.

\section{Cultured cells}

Embryonic cultured cells from 16-day gestation BALB/c embryos were prepared according to Arnheiter and Staeheli (1983). Briefly, embryos were minced and trypsinized after removal of head, limbs, and bowel. Cells were seeded at a density of $5 \times 10^{7}$ cells $/ 75-\mathrm{cm}^{2}$ tissue culture flask in DMEM supplemented with $10 \%$ FCS and antibiotics. Medium was changed after 1 day, and the cells were passaged every third day. Experiments were performed on cells of passages 3-5. The NIH-3T3 mouse fibroblast cell line was also maintained in DMEM containing $10 \%$ FCS plus antibiotics. For immunofluorescence, cells were grown on glass tissue culture chamber slides (Miles Labs, Inc.). Monolayer wounding experiments were performed on the above cells as follows: Cells were seeded in the chamber slides at a cell density sufficient to achieve confluent monolayers $48 \mathrm{hr}$ after culturing. At this time, a sterile razor blade was used to remove portions of the monolayer. The cutting and scraping created monolayer strips with defined borders adjacent to clearings with no cells. After scarring, the medium containing cell debris and free-floating portions of dislodged monolayer was removed by aspiration and replaced with fresh DMEM and $10 \%$ FCS and returned to the $37^{\circ} \mathrm{C} 5 \% \mathrm{CO}_{2}$ atmosphere. The wounded cultures were processed (as described below) for localization of the Hox 1.3 protein at intervals of 15 , $30,60 \mathrm{~min}$, or $18 \mathrm{hr}$ postwounding.

\section{Immunofluorescence}

Indirect immunofluorescent staining of the cultured cells, using peptide-specific anti-Hox 1.3 antisera, was performed essentially as described by Amheiter et al. (1984). Cultures were fixed with $3 \%$ formaldehyde (from paraformaldehyde) in PBS (pH 7.4) for $10 \mathrm{~min}$. After three 1- min rinses with PBS, the cells were permeabilized with $0.05 \%$ Triton X-100 in PBS for 10 min. Following three 5 -min rinses with PBS, containing 5\% normal goat serum (NGS), the cells were incubated for $20 \mathrm{~min}$ with rabbit anti-peptide A or B antisera diluted in PBS $15 \%$ NGS). For peptide-blocking controls, peptide $\mathrm{A}$ or $\mathrm{B}$ was added to the antisera dilution at a final concentration of $200 \mu \mathrm{g} / \mathrm{ml}$. Cells were then washed for $15 \mathrm{~min}$ with three changes of PBS (5\% NGS), as described above, and incubated for 20 min with $\mathrm{F}(\mathrm{ab})_{2}$ fluorescein-conjugated goat anti-rabbit IgG fragments (Cappel Labs) diluted in PBS ( $5 \%$ NGS). After three 5 -min rinses in PBS, the cells were covered with a thin layer of $50 \%$ glycerol in $100 \mathrm{~mm}$ Tris- $\mathrm{HCl}$ ( $\mathrm{pH} 8.5$ ), followed by a glass coverslip. All incubations and washes were performed at room temperature. The cells were observed and photographed with a Zeiss photoscope III equipped with epifluorescence.

\section{Preparation of crude nuclear extracts from cultured cells}

$\mathrm{NIH}-3 \mathrm{~T} 3$ cells were cultured in plastic petri dishes as described above. Crude nuclear extracts were prepared from confluent and nonconfluent cultures, as described by Persson and Leder (1984). Cells were washed and collected (centrifuged at $800 \mathrm{~g}$ for $2 \mathrm{~min}$ ) in ice-cold PBS. Cell pellets were resuspended in $0.02 \mathrm{M}$ HEPES buffer (pH 7.8): $1 \mathrm{mM} \mathrm{MgCl}, 0.5 \mathrm{mM} \mathrm{CaCl}_{2}, 1 \mathrm{mM}$ dithiotreitol, and $1 \mathrm{mM}$ phenylmethylsulfonyl fluoride (PMSF). After $10 \mathrm{~min}$ on ice, the cells were disrupted by 12 strokes with a tight-fitting Dounce homogenizer. The nuclei were separated from the cellular debris by centrifugation at $800 \mathrm{~g}$ for $2 \mathrm{~min}$. The pelleted nuclei were resuspended in RIPA buffer $[0.05 \mathrm{M}$ Tris$\mathrm{HCl}(\mathrm{pH} 7.5), 0.5 \mathrm{M} \mathrm{NaCl}, 0.1 \%$ SDS, $0.5 \%$ sodium deoxycholate, $1 \%$ Triton X-100, and $1 \mathrm{mM}$ PMSF], subjected to one freeze-thaw cycle followed by precipitation of the proteins with acetone. The precipitates were resuspended in $10 \mathrm{mM}$ Tris- $\mathrm{HCl}$ (pH 6.8), and their protein concentrations determined by a BioRad protein kit (Bio-Rad Labs).

\section{Immunoblot analysis}

Proteins from crude nuclei extracts were resolved by SDSpolyacrylamide gel electrophoresis and electroblotted onto nitrocellulose according to Towbin et al. (1979), using a Bio-Rad TransBlot cell (Bio-Rad Labs). ${ }^{14} \mathrm{C}$-Labeled protein standards (Bethesda Research Labs) were also resolved and blotted, and their electrophoretic mobilities used to estimate molecular weights of the transferred proteins. After transfer, blots were rinsed in $10 \mathrm{mM}$ Tris- $\mathrm{HCl}$ ( $\mathrm{pH} 8.0$ ) $150 \mathrm{mM} \mathrm{NaCl}$, and $0.05 \%$ Tween 20 (TBST). Excess nonspecific protein-binding sites on the membranes were saturated by a $30 \mathrm{~min}$ incubation in TBST containing 1\% Blot Qualified Bovine Serum Albumin (Promega Biotec). After blocking, blots were incubated with anti-peptide antisera diluted in TBST for $30 \mathrm{~min}$ on a rocker at room temperature, followed by three $10 \mathrm{~min}$ rinses in TBST to remove unbound antibody. For peptide-blocking controls, antisera dilutions contained either specific or nonspecific peptide 1200 $\mu \mathrm{g} / \mathrm{ml})$. Bound $\mathrm{IgG}$ was visualized with an anti-rabbit IgG-conjugated alkaline phosphatase reporter system (Promega Biotec). The conjugate, diluted in TBST, was incubated with the blots for $30 \mathrm{~min}$ at room temperature followed by three 10 -min rinses in TBST. The phosphatase substrate 15-bromo-4-chloro-3-indolyl phosphate) and chromogen (nitro blue tetrazolium) were 
prepared and used according to the manufacturer's instructions (Promega Biotec). ${ }^{14} \mathrm{C}$-Labeled protein standards were visualized by autoradiography.

\section{Immunocytochemistry of adult tissue}

Tissue immunolocalization studies were performed on tissue fixed by perfusion and stained by the peroxidase-antiperoxidase (PAP) technique (Sternberger 1979). Animals were anesthetized with chloral hydrate and fixed by vascular perfusion with $4 \%$ formaldehyde (from paraformaldehyde) in $0.1 \mathrm{M}$ sodium phosphate buffer ( $\mathrm{pH} 7.4)$, as described elsewhere (Friedrich and Mugnaini 1981). Fixation was terminated after $10 \mathrm{~min}$ by perfusion with $5 \%$ sucrose in the same buffer or with PBS. Brains and spinal cords were removed and stored overnight at $4^{\circ} \mathrm{C}$ in the final perfusate solution. Sections, $40-60 \mu \mathrm{m}$ thick, of unembedded brain and spinal cord were cut with a Vibratome (Oxford) and stored in $0.5 \mathrm{M}$ Tris- $\mathrm{HCl}$ buffer (pH 7.6) (TB). Sections were treated sequentially at room temperature with the following solutions: $0.25 \%$ Intra $\mathrm{X}-100$ in TB (10 min); $3 \%$ NGS in TB (15 min); anti-peptide A antisera diluted in TB or the same dilution of antisera containing peptide A or B $(200$ $\mu \mathrm{g} / \mathrm{ml}$ ) (overnight); goat anti-rabbit IgG (Cappel Labs) diluted to yield $150 \mu \mathrm{g} / \mathrm{ml}$ in TB (1-2 hr); TB wash (5-20 min) three times; rabbit PAP diluted to yield $35 \mu \mathrm{g} / \mathrm{ml}$ PAP complex in TB $(1-2$ hr); TB wash (5-20 min) three times; $0.01 \%$ hydrogen peroxide and $0.05 \%$ diaminobenzidine $(8 \mathrm{~min}) ;$ TB wash $(5-20 \mathrm{~min})$ three times. Sections were mounted on slides and coverslipped under a glycerol-saline solution or washed in a solution containing $40 \%$ ethanol and $0.12 \%$ gelatin in distilled water, dried on slides, and coverslipped under Permount. Sections were observed and photographed with a Zeiss photoscope III.

\section{Acknowledgments}

We are indebted to the members of the Laboratory of Molecular Genetics for their guidance and support throughout these studies. We are grateful to Drs. Michael Levine and William McGinnis for the gifts of the Drosophila homeo box clones and Drs. Anamaris M. Colberg-Poley and Peter Gruss for the Hox 1 genomic clone $(\lambda \mathrm{m}-6)$. We would also like to thank Drs. Victor Corces, John Kamholz, and Michael Myers for their encouragement and enthusiasm during the initial stages of this study. The technical expertise and assistance of Blanche Lewis and Brad Jones was invaluable. The authors are also grateful to Charlene French for preparation of this manuscript.

\section{Note added in proof}

After submission of this manuscript, Krumlauf et al. (Development 99: 603-617, 1987) communicated the predicted primary structure of the Hox 2.1 protein. The Hox 1.3 and Hox 2.1 proteins share extensive homology outside of their homeo domains. Twenty-three of their first 25 aminoterminal residues are identical.

\section{References}

Arnheiter, H. and P. Staeheli. 1983. Expression of interferon dependent resistance to influenza virus in mouse embryo cells. Arch.Virol. 76: 127-137.

Arnheiter, H., M. Dubois-Dalcq, and R.A. Lazzarini. 1984. Direct visualization of protein transport and processing in the living cell by microinjection of specific antibodies. Cell 39: $99-109$.

Awgulewitsch, A., M.F. Utset, C.P. Hart, W. McGinnis, and F.H. Ruddle. 1986. Spatial restriction in expression of a mouse homoeo box locus within the central nervous system. Nature 320: 328-335.

Beachy, P.A., S.L. Helfand, and D.S. Hogness. 1985. Segmental distribution of bithorax complex proteins during Drosophila development. Nature 313: 545-551.

Breathnach, R. and P. Chambon. 1981. Organization and expression of eucaryotic split genes coding for proteins. Annu. Rev. Biochem. 50: 349-383.

Búcan, M., T. Yang-Feng, A.M. Colberg-Poley, D.J. Wolgemuth, J.-L. Guenet, U. Francke, and H. Lehrach. 1986. Genetic and cytogenetic localisation of the homeo box containing genes on mouse chromosome 6 and human chromosome 7. EMBO I. 5: 2899-2905.

Carroll, S.B. and M.P. Scott. 1985. Localization of the fushi tarazu protein during Drosophila embryogenesis. Cell 443: 47-57.

Carroll, S.B., R.A. Laymon, M.A. McCutcheon, P.D. Riley, and M.P. Scott. 1986. The localization and regulation of Antennapedia protein expression in Drosophila embryos. Cell 47: $113-122$.

Colberg-Poley, A.M., S.D. Voss, K. Chowdhury, and P. Gruss. 1985a. Structural analysis of murine genes containing homoeo box sequences and their expression in embryonal carcinoma cells. Nature 314: 713-718.

Colberg-Poley, A.M., S.D. Voss, K. Chowdhury, C.L. Stewart, E.F. Wagner, and P. Gruss. 1985b. Clustered homeo boxes are differentially expressed during murine development. Cell 43: 39-45.

Desplan, C., J. Theis, and P.H. O'Farrell. 1985. The Drosophila developmental gene, engrailed, encodes a sequence-specific DNA binding activity. Nature 318: 630-635.

DiNardo, S., J.M. Kuner, J. Theis, and P.H. O'Farrell. 1985. Development of embryonic pattern in $D$. melanogaster as revealed by accumulation of the nuclear engrailed protein. Cell 43: 59-69.

Duboule, D., A. Baron, P. Mähl, and B. Galliot. 1986. A new homeo-box is present in overlapping cosmid clones which define the mouse Hox-1 locus. EMBO J. 5: 1973-1980.

Fainsod, A., L.D. Bogarad, T. Ruusala, M. Lubin, D.M. Crothers, and F.H. Ruddle. 1986. The homeo domain of a murine protein binds $5^{\prime}$ to its own homeo box. Proc. Natl. Acad. Sci. 83: 9532-9536.

Friedrich, V.L., Jr. and E. Mugnaini. 1981. Preparation of neural tissues for electron microscopy. In $A$ handbook of neuroanatomical tract tracing techniques (ed. L. Heimer and $M$. Robards), pp. 377-406, Plenum Press, New York.

Gallione, C.J., J.R. Greene, L.E. Iverson, and J.K. Rose. 1981. Nucleotide sequences of the mRNAs encoding the vesicular stomatitis virus $\mathrm{N}$ and NS proteins. I. Virol. 39: 529-535.

Garber, R.L., A. Kuroiwa, and W.J. Gehring. 1983. Genomic and cDNA clones of the homeotic locus Antennapedia in Drosophila. EMBO I. 2: 2027-2036.

Hart, C.P., A. Awgulewitsch, A. Fainsod, W. McGinnis, and F.H. Ruddle. 1985. Homeo box gene complex on mouse chromosome 11: Molecular cloning, expression in embryogenesis, and homology to a human homeo box locus. Cell 43: 9-18.

Harvey, R.P., C.J. Tabin, and D.A. Melton. 1986. Embryonic expression and nuclear localization of Xenopus homeobox (Xhox) gene products. EMBO J. 5: 1237-1244.

Hauser, C.A., A.L. Joyner, R.D. Klein, T.K. Learned, G.R. Martin, and R. Tjian. 1985. Expression of homologous 
homeo-box-containing genes in differentiated human teratocarcinoma cells and mouse embryos. Cell 43: 19-28.

Holland, P. and B. Hogan. 1986. Phylogenetic distribution of Antennapedia-like homeo boxes. Nature 321: 251-253.

Jackson, I.J., P. Scholfield, and B.L.M. Hogan. 1985. A mouse homoeo box gene is expressed during embryogenesis in adult kidney. Nature 317: 745-748.

Kamholz, J., F. de Ferra, C. Puckett, and R. Lazzarini. 1986. Identification of three forms of human myelin basic protein by cDNA cloning. Proc. Natl. Acad. Sci. 83: 4962-4966.

Kaufman, E., N. Geisler, and K. Weber. 1984. SDS-PAGE strongly overestimates the molecular masses of the neurofilament proteins. FEBS Lett. 170: 81-84.

Laughon, A. and M.P. Scott. 1984. Sequence of a Drosophila segmentation gene: Protein structure homology with DNAbinding proteins. Nature 310: 25-31.

Laughon, A., S.B. Carroll, F.A. Storfer, P.D. Riley, and M.P. Scott. 1985. Common properties of proteins encoded by the Antennapedia complex genes of Drosophila melanogaster. Cold Spring Harbor Symp. Quant. Biol. 50: 253-262.

Lewis, E.B. 1978. A gene complex controlling segmentation in Drosophila. Nature 276: 565-570.

Macdonald, P.M. and G. Struhl. 1986. A molecular gradient in early Drosophila embryos and its role in specifying the body pattern. Nature 324: 537-545.

Maniatis, T., E.F. Fritsch, and J. Sambrook. 1982. Molecular cloning: A laboratory manual. Cold Spring Harbor Laboratory, Cold Spring Harbor, New York.

Manley, J.L. and M.S. Levine. 1985. The homeo box and mammalian development. Cell 43: 1-2.

Martin, G.R., E. Boncinelli, D. Duboule, P. Gruss, I. Jackson, R. Krumlauf, P. Lonai, W. McGinnis, F. Ruddle, and D. Wolgemuth. 1987. Nomenclature for homoeo-box-containing genes. Nature 325: 21-22.

Mavilio, F., A. Simeone, A. Giampolo, A. Faiella, V. Zappavigna, D. Acampora, G. Poiana, G. Russo, C. Peschle, and E. Boncinelli. 1986. Differential and stage-related expression in embryonic tissues of a new human homoeobox gene. Nature 324: 664-668.

McGinnis, W. 1985. Homeo box sequences of the Antennapedia class are conserved only in higher animal genomes. Cold Spring Harbor Symp. Quant. Biol. 50: 263-270.

McGinnis, W., C.P. Hart, W.J. Gehring, and F.H. Ruddle. 1984a. Molecular cloning and chromosome mapping of a mouse DNA sequence homologous to homeotic genes of Drosophila. Cell 38: 675-680.

McGinnis, W., R.L. Garber, J. Wirz, A. Kuroiwa, and W.J. Gehring. 1984b. A homologous protein-coding sequence in Drosophila homoeotic genes and its conservation in other metazoans. Cell 37: 403-408.

Merrifield, R.B. and G. Barany. 1980. In The peptides, analysis, synthesis, biology (ed. E. Gross and J. Meinenhofer), vol. 2, Chapt. 1. Academic Press, New York.

Messing, J. 1983. New Ml3 vectors for cloning. Methods Enzymol. 101: 28-78.

Mount, S.M. and J.A. Steitz. 1984. RNA splicing and the involvement of small ribonucleoproteins. Mod. Cell Biol. 3: 249-297.

Nüsslein-Volhard, C. and E. Wieschaus. 1980. Mutations affecting segment number and polarity in Drosophila. Nature 287: 795-801.

Ouweneel, W. 1976. Developmental genetics of homoeosis. Adv. Genet. 16: 179-248.

Persson, H. and P. Leder. 1984. Nuclear localization and DNA binding properties of a protein expressed by human c-myc oncogene. Science 225: 718-721.
Regulski, M., K. Harding, R. Kostriken, F. Karch, M. Levine, and W. McGinnis. 1985. Homeo box genes of the Antennapedia and bithorax complexes of Drosophila. Cell 43: $71-$ 80.

Richardson, C., A. Berkovich, S. Rozenblatt, and W.J. Bellini, Ir. 1985. Use of antibodies directed against synthetic peptides for identifying cDNA clones, establishing reading frames, and deducing the gene order of measles virus. I. Virol. 54: $186-193$.

Rosenberg, U.B., C. Schröder, A. Preiss, A. Kienlin, S. Côté, I. Riede, and H. Jäckle. 1986. Structural homology of the product of the Drosophila Krüppel gene with Xenopus transcription factor IIIA. Nature 319: 336-339.

Rubin, M.R., L.E. Toth, M.D. Patel, P. D'Eustachio, and M.C. Nguyen-Huu. 1986. A mouse homeo box gene is expressed in spermatocytes and embryos. Science 233: 663-667.

Ruddle, F.H., C.P. Hart, A. Awgulewitsch, A. Fainsod, M. Utset, D. Dalton, N. Kerk, M. Rabin, A. Ferguson-Smith, A. Fienberg, and W. McGinnis. 1985. Mammalian homeo box genes. Cold Spring Harbor Symp. Quant. Biol. 50: 277-284.

Sanger, F., S. Nicklen, and A.R. Coulson. 1977. DNA sequencing with chain terminating inhibitors. Proc. Natl. Acad. Sci. 74: 5463-5467.

Schneuwly, S., A. Kuroiwa, P. Baumgartner, and W.J. Gehring. 1986. Structural organization and sequence of the homeotic gene Antennapedia of Drosophila melanogaster. EMBO J. 5: $733-739$.

Scott, M.P. and A.J. Weiner. 1984. Structural relationships among genes that control development: Sequence homology between the Antennapedia, Ultrabithorax, and fushi tarazu loci of Drosophila. Proc. Natl. Acad. Sci. 81: 4115-4118.

Shaw, G. and R. Kamen. 1986. A conserved AU sequence from the 3' untranslated region of GM-CSF mRNA mediates selective mRNA degradation. Cell 46: 659-667.

Shepherd, J.C.W., W. McGinnis, A.E. Carrasco, E.M. De Robertis, and W.J. Gehring. 1984. Fly and frog homoeo domains show homologies with yeast mating type regulatory proteins. Nature 310: 70-71.

Sternberger, L.A. 1979. Immunocytochemistry. John Wiley, New York.

Towbin, H., T. Staehelin, and J. Gordon. 1979. Electrophoretic transfer of proteins from polyacrylamide gels to nitrocellulose sheets: Procedure and some applications. Proc. Natl. Acad. Sci. 76: 4350-4354.

Wieser, R.J. and F. Oesch. 1986. Contact inhibition of growth of human diploid fibroblasts by immobilized plasma membrane glycoproteins. I. Cell Biol. 103: 361-367.

White, R.A.H. and M. Wilcox. 1984. Protein products of the bithorax complex in Drosophila. Cell 39: 163-171.

Wirz, J., L.I. Fessler, and W.J. Gehring. 1986. Localization of the Antennapedia protein in Drosophila embryos and imaginal discs. EMBO I. 5: 3327-3334.

Wolgemuth, D.J., E. Engelmyer, R.N. Duggal, E. Gizang-Ginsberg, G.L. Mutter, C. Ponzetto, C. Viviano, and Z.F. Zakeri. 1986. Isolation of a mouse cDNA coding for a developmentally regulated, testis-specific transcript containing homeo box homology. EMBO /. 5: 1229-1235. 


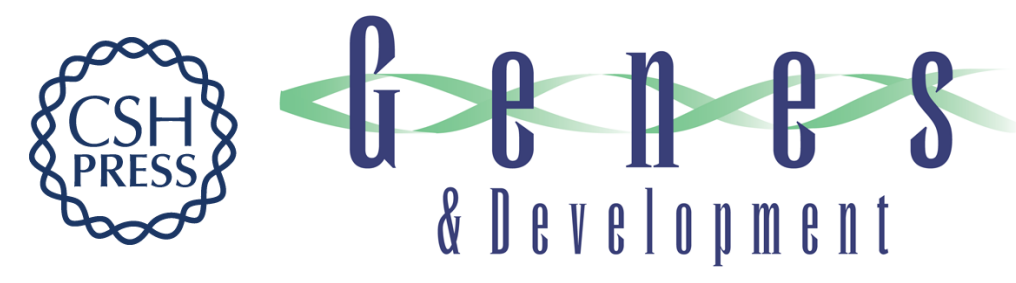

\section{Expression of a homeo domain protein in noncontact-inhibited cultured cells and postmitotic neurons.}

W F Odenwald, C F Taylor, F J Palmer-Hill, et al.

Genes Dev. 1987, 1:

Access the most recent version at doi:10.1101/gad.1.5.482

References This article cites 53 articles, 13 of which can be accessed free at:

http://genesdev.cshlp.org/content/1/5/482.full.html\#ref-list-1

License

Email Alerting Receive free email alerts when new articles cite this article - sign up in the box at Service the top right corner of the article or click here.

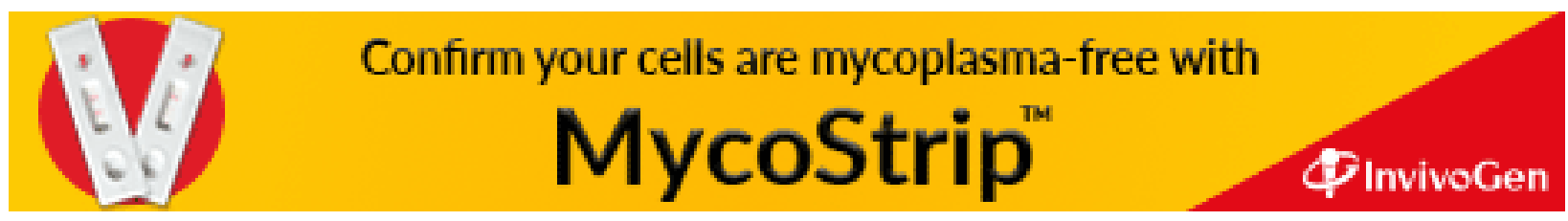

